\title{
BRAND RELATIONSHIPS ON RETAILING: THE IMPACT OF IMAGE ON BEHAVIORAL INTENTIONS OF CONSUMERS
}

Recebido - 29.12.10

Aceito - 14.03.2011

\author{
Euler Alves Brandão ${ }^{1}$, Reynaldo Maia Muniz² ${ }^{2}$ Cid Gonçalves Filho ${ }^{3}$, \\ Gian Franco Rocchiccioli ${ }^{4}$, Gustavo Quiroga Souki ${ }^{5}$ e Renata Livramento ${ }^{6}$
}

\begin{abstract}
The electronics retail market has been growing in a remarkable way. On the other hand, the strong competition in retail and the fact that the same retailers sell products of similar brands and models, poses a significant challenge for its differentiation. That's the purpose of this work, which aims at proposing a scale that measures these retailers' image, identifying the factors that impacted this image the most, as well as verifying the possible impacts of the image in the consumers' behavioral intentions. Thus, 48 detailed interviews and 4 discussion groups were carried out plus 490 questionnaires. After the scales were validated, a structural model was tested. It was observed that that the Instrumental elements, followed by the factors Products and Appearance/ Assistance in the Store were the ones that caused the biggest impact in the retailer's Image. On the other
\end{abstract}

1 President of Stetik Group, PhD student at Federal University of Minas Gerais (UFMG), MSc in Business Administration at Federal University of Santa Catarina (UFSC). Affiliation: UFMG/Stetik Group. Brazil. E-mail: euler@stetikgroup.com.br

2 Doctor in Political Sciences and Public Management, Universidad Complutense de Madrid, MSc in Political Sciences at Federal University of Minas Gerais (UFMG), Professor and Researcher at at Federal University of Minas Gerais (UFMG). Affiliation: UFMG. Brazil. E-mail: reynaldo@reitoria.ufmg.br

3 Doctor in Business Administration at Federal University of Minas Gerais (UFMG), MSc in Information Science (UFMG), Professor and Researcher at FUMEC, Brazil, Director of DataConsumer. Affiliation: Fumec University/ DataConsumer. Brazil. E-mail: cid@consumer.com.br

${ }^{4}$ CEO of Sart/Dreamaker Brand and Design, author of "The Secret of Ebbinghaus" (book about branding), Consultant and Adman. Affiliation: Stetik Group. Brazil. E-mail: gian@sdgroup.com.br

5 Doctor in Business Administration (UFLA), MSc in Business Adminstration at Federal University of Lavras (UFLA), Professor and Researcher at UNA, Brazil, Director of DataConsumer. Affiliation: UNA/DataConsumer. Brazil. Email: souki@consumer.com.br

6 PhD Student at Fumec University Brazil, MSc. in Business Administration at Fumec University. Affiliation: Fumec University. Brazil. E-mail: relivramento@yahoo.com.br 
hand, the Image presented a high impact in the purchase intention and word of mouth communication, which is determinant for these retailers' performance in the market. The article contributes with the development of Image scale for Electronics' Retailers as well as in the evidence of the significant impacts of this image in the behavioral intentions. The image scale can also be applied by retailers in a managerial way as an image diagnosis and comparative measurement with competitors.

Keywords: Retail. Image. Purchase intention. Brand relationships.

\section{INTRODUCTION}

The electronics retail market has a significant role in the Brazilian economy: only four of its most important representatives showed sales of US\$ 9,47 billion in 2006 and two of them (Casas Bahia and Ponto Frio) feature in the list of the 100 biggest companies in this country in the same year (MAIORES E MELHORES, 2007). Besides, the components of this sector are big investors in advertising: Casas Bahia is listed as the biggest Brazilian advertiser since 2005 and in 2007 nothing less than three electronic retailers feature in the list of the country's thirty largest advertises (Ibope Monitor, 2008). On the other hand, image has been considered a major antecedent in the purchase behavior of consumers (MAY, 1974; LINDQUIST, 1975; DONOVAN; ROSSITER, 1982).

Despite these facts, studies about retailers' images are quite scarce, especially those that try to identify the image impact on the behavioral intentions of consumers. The image measurement scales of existing retailers are usually quite simple and do not focus on the electronics retailers specifically, despite the fact that this is a market that involves high sums of money and is the largest advertiser market in Brazil. This way, aiming at validating a Retailers' Image scale, this research proposed to analyze its factors and verify the image impacts on the behavioral intention of consumers.

\section{LITERATURE REVIEW}

\subsection{The image studies perspectives}

In ancient Greek, the word "image" corresponds to Eidos, which is the etymological root of the idea, or Eidea developed by Plato. In this sense, image is the idea a person has about something, that is, a mind projection concerning objects, people, situations, etc. It is therefore, a subjective representation about something (SALLES, 2004).

I firstly call images the shadows, then the reflections we see on the water or on the surface of opaque, polished and brilliant bodies, and all similar representations' (PLATO, 1996).

\subsubsection{Perspective of cognitive psychology}

Cognitive psychology is a school of thought in Psychology that deals with how people perceive, learn, structure, store and use knowledge / information (STERNBERG, 2000). In this view, the images are visions, perceptions, imaginings, models and mental representations of each subject (DE TONI, 2005). Therefore, among the various areas of interest for cognitive 
psychologists, two are particularly relevant for studies of images: the perception and representation of knowledge.

Perception is understood as the "set of psychological processes by which people recognize, organize, synthesize and provide meaning (the brain) to the sensations received from environmental stimuli (the sensory organs) (STERNBERG, 2000, p. 147). In order to have the formation of a concept or image of an object, it is necessary that the subject has first perceived this object (EYSENC; KEANE, 1994).

\subsubsection{The perspective of semiotics}

Semiotics (from the Greek semeiotike or "the art of signs") is the general science of signs and semiotics, which studies all the cultural phenomena as if they were sign systems, that is, signification systems. It is the study of the process of signification or representation, in nature and culture, of the concept and idea. As an object, this science has any sign system such as the cinema, photography, music, gestures among others (HOUAISS, 2008).

The concept of representation is a central concept in Semiotics, but, just like the image concept, there is not a consensus in literature about its definition. Its main use has been as a synonym of sign, that is, "something that, under the aspect and somehow, represents something for someone" (PIERCE apud IASBEECK, 1999). The designation "sign" refers to the triad relation between a sign, its object and the interpreting thought (BACHA, 2005).

\subsection{3- The marketing perspective}

The Image Theory is dealt with in Marketing through different ways and there is no consensus neither about the concept nor the process of image formation (POIESZ, 1989; DOBNI; ZINKHAN, 1990; KEAVENEY; HUNT, 1992; STERN; ZINKHAN; JAJU, 2001).

In the fifties, Kenneth Boulding published a book called "The Image", which became a reference to the study of image. His work approaches the role of images in different areas of man's interest such as history, the sociology of knowledge, theory of organizations and economic activities among others. According to this author, human behavior depends on the images that people build: "The first proposition of this work, therefore, is that behavior depends on the Image" (BOULDING, 1966, p. 6).

However, the images do not necessarily reflect a "truth". Even though they are considered reality, images are based on a subjective perception of reality and can, therefore originate from false assumptions (AAKER, 1991; IASBECK, 1999). This characteristic becomes clear in Socrates' cave allegory, narrated by Plato (1996) to illustrate his thought that truth is not accessible to the human eye.

Considering then that people's behavior is motivated by images, this theme becomes extremely interesting for marketing theorists, who try to understand consumers' behavior. Based on that, the image has been used in brand management, stores, products, organizations and professions (BOULDING, 1956; MARTINEAU, 1957; LINDQUIST, 1975; DICHTER, 1985; DOBNI; ZINKHAN, 1990; BARICH; KOTLER, 1991; ZINKHAN; JAJU, 2001; ITUASSU, 2004, DE TONI; MILAN; SCHULER, 2004, 2005; GRASSELI, 2007; GRASSELI; SOUKI, 2007, AMORIM, 2007; SOUKI; AMORIM; MENDES, 2008). Such perspectives will be discussed in detail afterward.

- The Store Image

The concept of Store Image was introduced by Pierre Martineau (1958) as "the way a store is defined in the consumer's mind, partly due to its functional qualities and partly due to an aura of psychological attributes" (MARTINEAU, 1958, p. 47). According to Stern, Zinkhan and Jaju (2001), the store image definitions can be classified in three categories, according to the 
following emphasis: functional elements (store image as part of retail strategy), psychological elements (store image determined by the consumer's mind) and complex configurations or "gestalt" (creation of a unified image concept from the group of its functional, psychological and symbolic elements), as seen on Table 1.

Table 1 - Definitions of store image

\begin{tabular}{|c|c|c|}
\hline \multicolumn{3}{|c|}{ EMPHASIS ON FUNCTIONAL ELEMENTS } \\
\hline Year & Author(s) & Definition \\
\hline 1961 & Weale & $\begin{array}{l}\text { The consumer evaluates the store image considering price, quality and customer } \\
\text { services offered. }\end{array}$ \\
\hline 1979 & Ring & $\begin{array}{l}\text { The sum of strategy and tactics adopted by the store makes up the image that the } \\
\text { store presents to its consumers }\end{array}$ \\
\hline 1981 & Kasulis and Lusch & $\begin{array}{l}\text { The store projects a personality to the consumer through its characteristics, } \\
\text { employees, market strategies, etc. }\end{array}$ \\
\hline 1984 & Hooley and Cook & $\begin{array}{l}\text { The current store image names the beliefs of consumers and potential consumers } \\
\text { on what the store offers them in terms of retail mix }\end{array}$ \\
\hline \multicolumn{3}{|c|}{ EMPHASIS ON PSYCHOLOGICAL ELEMENTS } \\
\hline 1958 & Martineau & $\begin{array}{l}\text { Way the store is defined in the consu mer's mind, partly because of its functional } \\
\text { qualities and partly by an aura of psychological attributes }\end{array}$ \\
\hline 1961 & Arons & $\begin{array}{l}\text { It is the personality of the store presented to the public: a complex of meanings } \\
\text { and associations that characterize the store to people. }\end{array}$ \\
\hline 1968 & Kunkhal and Berry & $\begin{array}{l}\text { Discriminative stimulus for the enhancement of an expected action. Specifically, } \\
\text { store image is the total increase expected or idealized that a person associates to } \\
\text { buying at that particular store }\end{array}$ \\
\hline 1974 & Doyle and Fenwick & $\begin{array}{l}\text { The attitude about the store, to describe the overall impression that the consumer } \\
\text { gets from it. }\end{array}$ \\
\hline 1980 & Hirschman & $\begin{array}{l}\text { A subjective phenomenon that results from acquiring knowledge about the store } \\
\text { in accordance to the individual, mental or cognitive model of the consumer. }\end{array}$ \\
\hline 1985 & Hite and Belizzi & $\begin{array}{l}\text { What the consumer sees is a combination between tangible or functional factors } \\
\text { and intangibles or psychological factors. }\end{array}$ \\
\hline \multicolumn{3}{|c|}{ EMPHASIS ON COMPLEX CONFIGURATION (GESTALT) } \\
\hline 1974 & May & $\begin{array}{l}\text { It is a compound of dimensions perceived by consumers, and the importance of } \\
\text { each dimension depends on the store itself and the consumer that purchases } \\
\text { there. }\end{array}$ \\
\hline 1976 & Marks & It is a synergy of individual perceptions, associated to the dimensions of the store. \\
\hline 1986 & $\begin{array}{l}\text { Mazursky and } \\
\text { Jacob }\end{array}$ & $\begin{array}{l}\text { Store image is: (1) An idiosyncr atic cognitive configuration and / or an effect (or } \\
\text { set of cognitions and / or effects), (2) that are inferred, (3), or from one set of } \\
\text { perceptions and / or memories related to the phenomenon (eg an object or event } \\
\text { as a store, product, etc.), and (4) that represents what the phenomenon means to } \\
\text { an individual. }\end{array}$ \\
\hline
\end{tabular}

Source: Adapted from Stern, Zinkhan and Jaju (2001).

As a functional element, image is part of the retail strategy and involves more tangible aspects that can be compared more objectively to those of the competition such as: merchandise, credit policies, price, store layout, store location, parking, product quality and services, among 
others (LINDQUIST, 1975; ZIMMER; GOLDEN, 1988). In this respect, Swan and Futrell (1980) consider that the store image study is a way for the retailer to have an idea of his business according to his clients' view. Thus, the authors see the store image as being of great importance for the operational and market efficiency (SWAN; FUTRELL, 1980). Kasulis and Lush (1986), reasserting Dischter's view (19850, add that the store image can be changed by the retailer without changing the objective characteristics, since the store reflects the consumers' perceptions (KAUSULIS; LUSCH, 1986).

- Brand/Product image

Although they do not mean the same, the brand image and the product image are often presented as synonyms in marketing literature. But as clarified by Dobni and Zinkhan (1990), the brand image is generally focused on symbolic, emotional and cognitive attributes, and the product image also emphasizes functional aspects (DOBNI; ZINKHAN, 1990). Studies show that the images consumers have about a brand or product influence their purchase behavior, and many times they buy a product not for its characteristics, but for what the brand or product represent to them (LEVY, 1958).

Stern, Zinkhan and Jaju (2001) point out two characteristics in common in the definition of brand image: (1) the brand image is a gestalt construction, and (2) the brand image is a transactional process between the brand stimulus and the consumer's perception. In this process, the consumer has a holistic impression about the brand position in relation to its competitors, working as: (1) a way to reduce the extension and complexity of the processing, storage and recovery of information; (2) a precursor of a more complex elaborative process; (3) something that simplifies the purchasing process; (4) a persuasive sign for small and temporary attitude modification (POIESZ, 1989). Such dimensions can be better observed on table 2 .

According to Tavares (1998), brand image can be defined as a group of associations and values established between the brand and the consumer. These associations, in turn, come from perceptions originated from individual experience as well as from messages transmitted by communication. However, it is from the perceptive process that the signification notions are built, which are converted into connection, importance and valorization links. With this approach, we see that brand managers do not even come close to having control over a brand image, since it is formed by a group of perceptions that only complete themselves from an individual's references and values. Brand image is then, built over a constant interaction between the brand itself and human beings (TAVARES, 1998).

Using the following definition for perception: "It is the process through which an individual selects, organizes and interprets information received from the environment" (SHETH et al. 2001, p. 286), we can conclude that only knowing better the process through which our perception is achieved, will we be able to find the right path for a correct brand management. Sheth (2001) proposes four phases in the process of information by the consumer:

1. Stimulus;

2. Sensation (Stimulus is collected);

3. Organization (Stimulus is compared to what is in the memory);

4. Interpretation (Adds meaning to stimulus). 
Table 2 - Definitions of brand/product image

\begin{tabular}{|c|c|c|}
\hline \multicolumn{3}{|c|}{ GENERAL EMPHASIS } \\
\hline Year & Author(s) & Definition \\
\hline 1957 & Newman & Identifies which product is a sum of meanings it communicates \\
\hline 1963 & Herzog & $\begin{array}{l}\text { States that the image brand is the total sum of impressions the consumer receives } \\
\text { from many sources }\end{array}$ \\
\hline 1985 & Dicher & The product/brand images indicate a set of impressions present in people's mind \\
\hline \multicolumn{3}{|c|}{ EMPHASIS ON SYMBOLISM } \\
\hline Year & Author(s) & Definition \\
\hline 1958 & Levy & People buy objects not only by what they can do, but also for what they mean, \\
\hline 1973 & $\begin{array}{l}\text { Pohlman and } \\
\text { Mudd }\end{array}$ & $\begin{array}{l}\text { Two types of value: a functional value that expresses the product usefulness, and } \\
\text { a symbolic value (image). }\end{array}$ \\
\hline 1988 & Noth & $\begin{array}{l}\text { Semiotic perspective: product and brand studied as signs. The semantic } \\
\text { components of branding in clude technical issues, product features, financial } \\
\text { worth or social appropriateness. }\end{array}$ \\
\hline \multicolumn{3}{|c|}{ EMPHASIS ON THE MEANING OR MESSAGE } \\
\hline Year & Author (s) & Definition \\
\hline 1973 & Levy and Glick & $\begin{array}{l}\text { The consumer buys a product not only by its functional and physical attributes, } \\
\text { but al so for the meaningful connection with the product or brand. Image is an } \\
\text { interpretation, a set of inferences and reactions, since it is not the object itself, but } \\
\text { refers to it }\end{array}$ \\
\hline 1967 & $\begin{array}{l}\text { Grubb and } \\
\text { Grathwol }\end{array}$ & Physical or symbolic value of the purchased product in the market \\
\hline 1983 & Swartz & $\begin{array}{l}\text { In the symbolic consumer behavior, the interest is to investigate the role of the } \\
\text { products as "messages" or "non-verbal communication", sent by users/owners. }\end{array}$ \\
\hline 1993 & Bromley & $\begin{array}{l}\text { The image brand is not simply a set of attributes, but it is a declaration on what } \\
\text { the product means to the consumer }\end{array}$ \\
\hline
\end{tabular}

Source: Adapted from Stern, Zinkhan and Jaju (2001). 
Table 2 - Definitions of brand/product image (Cont.)

\begin{tabular}{|c|c|c|}
\hline \multicolumn{3}{|c|}{ ENPHASIS ON PERSONIFICATION } \\
\hline Year & Author(s) & Definition \\
\hline 1985 & Sirgy & $\begin{array}{l}\text { The products } h \text { ave a personality image determined by physical features, } \\
\text { advertisement, and other Marketing and psychological associations }\end{array}$ \\
\hline 1985 & $\begin{array}{l}\text { Hendo and } \\
\text { Williams }\end{array}$ & $\begin{array}{l}\text { Brand personality or brand character involves a product description as if it were a } \\
\text { human being }\end{array}$ \\
\hline \multicolumn{3}{|c|}{ EMPHASIS ON COGNITIVE OR PSYCHOLOGICAL FACTORS } \\
\hline Year & Author(s) & Definition \\
\hline 1955 & Gardner and Levy & $\begin{array}{l}\text { A group of ideas, feelings and attitudes that the consumer has about the } \\
\text { product/brand. The social and psychological nature of the product. }\end{array}$ \\
\hline 1965 & Reynolds, W. & $\begin{array}{l}\text { The image is a mental construction developed by the consumer. They are } \\
\text { inference systems, it's a whole ordered and built by the consumer, starting from } \\
\text { parts to illuminate the complexity of the whole. }\end{array}$ \\
\hline 1970 & $\begin{array}{l}\text { Bird, Channon and } \\
\text { Ehrenberg }\end{array}$ & Brand image is an attitude about a specific brand. \\
\hline 1978 & Genseh & $\begin{array}{l}\text { Brand preference is a function of perception associated to alternatives. The brand } \\
\text { image has a significant role in situations where the individual has difficulty } \\
\text { obtaining a measurement of the important attributes of the product. }\end{array}$ \\
\hline 1984 & Bullmore & Brand image is what people think and feel about it. \\
\hline 1987 & $\begin{array}{l}\text { Friedmamn and } \\
\text { Leissig }\end{array}$ & $\begin{array}{l}\text { Psychological meaning. The consumer's comprehension and evaluation of the } \\
\text { product. }\end{array}$ \\
\hline
\end{tabular}

Source: Adapted from Stern, Zinkhan and Jaju (2001).

Still according to Sheth (2001), this process happens in three complementary phases: sensation, organization and interpretation. Sensation refers to the attention an object or event can arouse in an individual through his senses (vision, hearing, smell, touch and taste). This object or event is called stimulus. The organization phase is about the classification of this stimulus, perceived according to similar categories the individual has stored in his memory. In this phase, the consumer that tries wine, for example, will classify it as similar or different from others he has already drank. The following phase is called interpretation phase, on which is added a particular meaning to the initial stimulus. It is exactly in this phase that the consumer judges and establishes values to a product. 
- Corporate Image/Marketing Image

The brand image concept is related to the corporate image. According to Haedrich (1993), the relation between these two kinds of image is undeniable, since a company market behavior has a considerable influence on the way people see this company. This author thinks it is harder to build a corporate image than a brand image $(\mathrm{HAEDRICH}, 1993)$. Stern, Zinkhan and Jaju (2001) present some definitions of corporate image from a historical revision of different theoretical perspectives. The main concepts can be seen on table 3 .

Table 3 - Definitions of corporate image

\begin{tabular}{|c|c|c|}
\hline Ano & Author(s) & Definition \\
\hline 1958 & Martineau & $\begin{array}{l}\text { Image is a stereotype formed by the public based on functional meanings (quality, } \\
\text { service, and price) as well as emotional meanings. }\end{array}$ \\
\hline 1962 & Hill & $\begin{array}{l}\text { An abstraction about the organization based on sensorial impressions received by } \\
\text { an individual. The company's image varies a lot from public to public. }\end{array}$ \\
\hline 1978 & $\begin{array}{l}\text { Marton and } \\
\text { Boddewyn } \\
\end{array}$ & $\begin{array}{l}\text { Corporate image has a qualitative nature. It's refers to the total impression, } \\
\text { perception or reputation of the organization. }\end{array}$ \\
\hline 1982 & Pharoah & $\begin{array}{l}\text { Corporate image refers to the expectati ons, attitudes and feelings the consumer } \\
\text { has about the nature and the organization's implied reality, as represented by its } \\
\text { identity. }\end{array}$ \\
\hline 1984 & Gronroos & It's the result of how the consumers perceive the company \\
\hline 1986 & Dowling & $\begin{array}{l}\text { Group of meanings by which the orga nizations is known, which relates to this } \\
\text { organization and uses these meanings to describe it. The organization has no } \\
\text { image, people form an image of the organization. }\end{array}$ \\
\hline $1986 / 88$ & Winters & Corporate image is described by the public's attitude toward the organization. \\
\hline 1990 & $\begin{array}{l}\text { Johnson and } \\
\text { Zinkhan }\end{array}$ & It's the organization's general impression, formed by a part of the public. \\
\hline 1998 & Garone & It's the combination of an organization's reputation, brands and messages. \\
\hline
\end{tabular}

Fonte: Adaptado de Stern, Zinkhan e Jaju (2001).

The authors say that there are three points in common in the definitions of corporate image: (1) the image is an impression or perception located in the stakeholders' mind; (2) different groups form different images; and (3) image is a general gestalt impression. They consider as well that the change in the emphasis of the corporation itself to the emphasis in the perception of stakeholders is an important research effort (STERN; ZINKHAN; JAJU, 2001).

\subsubsection{Image dimensions}

The entity that incites an image can be an object, a person, a thought, or anything an individual experiences and creates an image of in his mind (ENIS, 2001). This author still remarks that the distinction between image and attitude is merely verbal and he uses Katz and Stoltant's work (1959) to indicate the three components of attitude (image): cognitive, affective and 
behavioral (KATZ; STOLTANT, 1959; ENIS, 2001). As for Haendrics (1993), he differentiates the concepts of attitude and image, but he also considers that the latter presents several dimensions, with cognitive and emotional elements.

Based on the revision work about image concepts developed by Dobni and Zinkhan (1990), De Toni, Milan and Schuler $(2004,2005)$ substantiated the existence of four important dimensions (cognitive, functional, emotional and symbolic) for the study on services image. These dimensions are described below:

Cognitive dimension: refers to the mental, rational and logical constructs that consumers use to evaluate services/products. The person's thoughts, perceptions, impressions, judgment and attitudes before the service provider are situated in this dimension. Aspects such as costbenefit, service quality, expectation fulfillment, etc. are examples of elements in this dimension. .(MARTINEAU, 1958; DICHTER, 1985; DOBNI; ZINKHAN, 1990; DE TONI; MILAN; SCHULER, 2005).

Functional dimension: it is constituted of tangible elements of service providing, usually related to the physical aspects such as quality and comfort of facilities, the service provider physical appearance, printed material, equipment, etc. (STERN; ZINKHAN; JAJU, 2001; DE TONI; MILAN; SCHULER, 2005; LOVELOCK; WRIGHT, 2005).

Emotional dimension: it is composed of feelings, emotions and state of mind induced by the direct contact and/or the subject's association with the service provided. This dimension encompasses elements such as fear, anger, joy and excitement among others (REYNOLD; GUTMAN, 1989).

Symbolic dimension: it is related to meanings the consumer gives to services provided. The symbol is something that represents or expresses more than the service itself, such as values, social patterns, self-image, etc. (MARTINEAU, 1958; LEVY, 1959; DICHTER, 1985; DOBNI; ZINKHAN, 1990; STERN; ZINKHAN; JAJU, 2001).

Thus, this work will consider these four dimensions concerning the construction of an image measurement questionnaire, referring to the authors mentioned above. Such dimensions are shown on figure 1.

Figure 1 - Image Evaluation Model

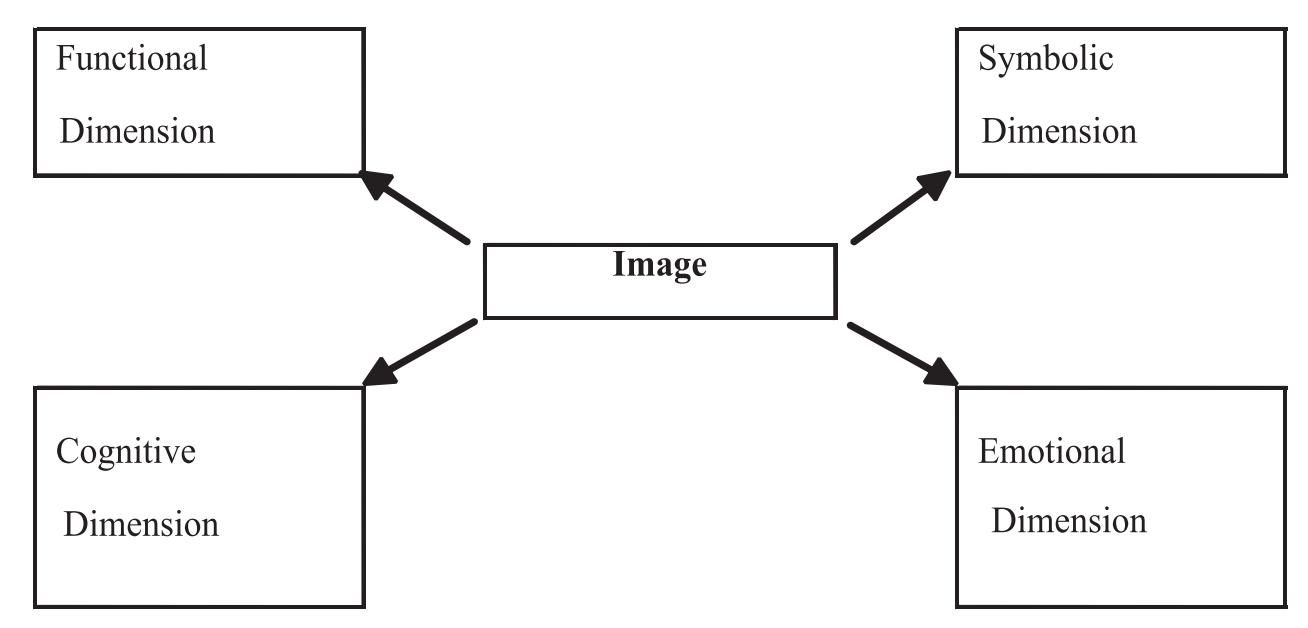

Source: Grasseli and Souki (2007). 


\section{HYPOTHETICAL RESEARCH MODEL}

The propositions of Hooley and Cook (1984) and Levy (1988) suggest that image has a positive influence on the purchase intention. According to this proposition, $\mathrm{H} 1$ hypothesis was elaborated:

H1: There is a positive impact of the retailers' image on the consumers' purchase intention.

On the other hand, Barich and Kotler (1991) and Garone consider (1998) that image has a positive relation to trust, suggesting the elaboration of hypothesis 2 :

$\mathrm{H}$ 2: There is a positive impact of the retailers' image on the consumers' trust about these retailers.

Considering Polhman and Mudd's revision (1993), as well as that of Grubb and Grathwol (1967), there is a possible image impact in the word of mouth communication, which led to the elaboration of hypothesis 3 :

H3: There is a positive impact of the retailers' image on the word of mouth communication.

According to Garone (1998) and Bodenwyn (1978) image would have a positive relation with perceived value, which led to the elaboration of hypothesis 4:

$\mathrm{H} 4$ : There is a positive impact of the retailers' image on the perceived value.

The hypothetical model proposed is presented in figure 2 .

Figure 2 - Hypothetical Model Search. Source: authors.

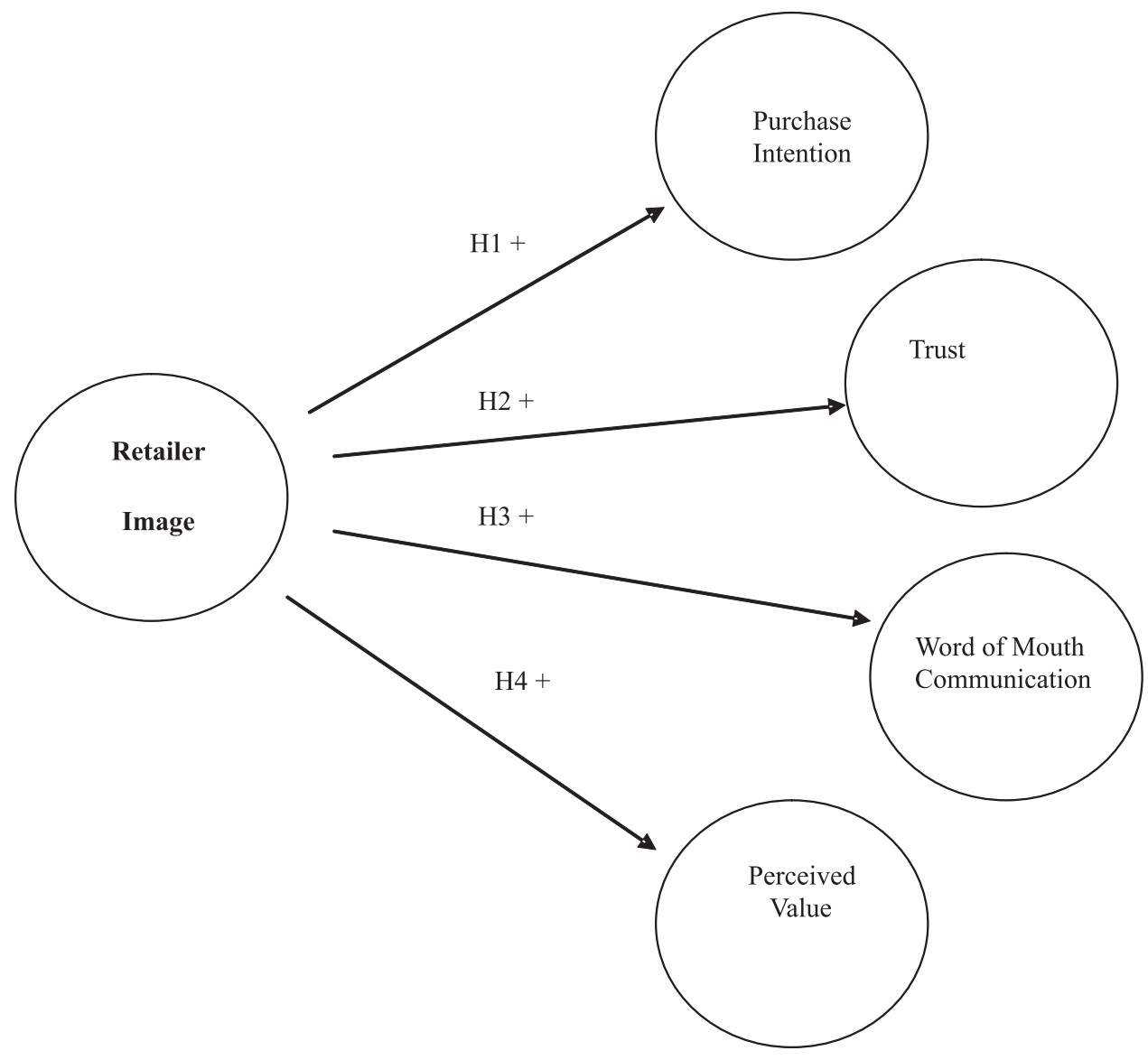




\section{METHODOLOGY}

In the initial, exploratory stage, 48 detailed interviews were carried out with consumers of Social Classes ABCD as well as four discussion groups (also distributed in the classes ABCD). Such a phase aimed at outlining image dimensions and exploring the problem, generating a base to create the proposed image scale along with the review of previous studies.

Afterwards, a survey with 490 interviewees was carried out between August and September 2010, in Belo Horizonte, capital of the state of Minas Gerais, Brazil.

The image scale was created from the suggested dimensions and scales of the authors mentioned as follows: Cognitive Dimension (MARTINEAU,1958; DICHTER, 1985; DOBNI; ZINKHAN, 1990; DE TONI; MILAN; SCHULER, 2005); Functional Dimension (STERN; ZINKHAN; JAJU, 2001; DE TONI; MILAN; SCHULER, 2005; LOVELOCK; WRIGHT, 2005); Emotional Dimension (REYNOLD; GUTMAN, 1994; POIESZ, 1989); Symbolic Dimension (MARTINEAU, 1958; LEVY, 1959; DICHTER, 1985; DOBNI; ZINKHAN, 1990; STERN; ZINKHAN; JAJU, 2001), as well as the ones for the interviews and discussion groups. The behavioral intentions used scales of Zeithaml, Berry and Parasuraman (1996).

\section{DATA ANALYSIS}

\subsection{Data exploratory analysis}

\subsubsection{Sample characterization}

It was verified that $52 \%$ of the respondents are men and $48 \%$ are women. Concerning the marital status of the respondents, fifty per cent are married or have a stable union; $35 \%$ are single, only $8 \%$ are divorced /separated and $4 \%$ are widowed.

\subsubsection{Analysis and treatment of missing values}

Questionnaires with missing values of more than $10 \%$ would be eliminated; otherwise the answers validity would be compromised. So, 10 out of the 500 questionnaires were excluded. After this exclusion, the missing values were still 1115 , which represent $6 \%$ of the total of answers. To verify if these missing values are random or not, it was applied the procedure suggested by Hair et al. (2005).

\subsubsection{Linearity analysis}

The analysis was carried on, since the nonlinear effects found, represent just a small portion of variation (5\%) in this kind of association among the indicators. Therefore, it does not imply absence of linearity (HAIR et al., 2005) or substantial loss of information contained in the data matrix (RAMALHO, 2006)

\subsubsection{Data reliability analysis}

\subsubsection{Constructs dimensionality and internal reliability}

To define the number of factors, the eigenvalue criterion was used initially, that is, only factors that presented eigenvalues (amount of variance explained by a factor) greater than 1 
were considered as significant (HAIR et al., 2005). To verify if the scale is free of random mistakes, the scale reliability analysis is carried out (MALHOTRA, 2006). The measurement usually used to verify the reliability of a scale for consumer's behavioral studies is the Alfa by Cronbach.

The solution presented the measures of Kaiser-Meyer-Olkin, Bartlett's Sphericity Test, explained Variance, Communality and Cronbach's Alpha are within acceptable limits. These results are presented at table 4 .

Table 4 - Retailers image - factorial solution

\begin{tabular}{|c|c|c|c|c|c|}
\hline Factor & Item & $V^{a}$ & $\mathrm{H}^{2 b}$ & $\mathrm{CF}^{\mathrm{c}}$ & $\begin{array}{l}\text { Alfa of } \\
\text { Cronbach }\end{array}$ \\
\hline \multirow{12}{*}{$\begin{array}{l}\text { F1 - Emotional } \\
\text { Aspects }\end{array}$} & B5.33) This store chain makes me feel ... & \multirow{12}{*}{19,68} & 0,748 & 0,820 & \multirow{12}{*}{0,955} \\
\hline & Angry / happy & & & & \\
\hline & B5.34) This store chain makes me feel... & & 0,802 & 0,862 & \\
\hline & Frustrated / Satisfied & & 0,002 & 0,002 & \\
\hline & $\begin{array}{l}\text { B5.35) This store chain makes me fell ... } \\
\text { ashamed / Proud }\end{array}$ & & 0,775 & 0,785 & \\
\hline & B5.36) This store chain makes me fell ... & & 0,849 & 0,896 & \\
\hline & Anxious / Calm & & & & \\
\hline & B5.37) This store chain makes me fell ... & & 0,851 & 0,897 & \\
\hline & Disrespected / Respected & & & & \\
\hline & B5.38) This store chain makes me fell ... & & 0.859 & 0912 & \\
\hline & Insecure / Secure & & ניכ, & 0,012 & \\
\hline & $\begin{array}{l}\text { B5.39) This store chain makes me fell ... } \\
\text { Bad / Good }\end{array}$ & & 0,842 & 0,891 & \\
\hline \multirow{6}{*}{$\begin{array}{l}\text { F2 - Instrumental } \\
\text { Aspects }\end{array}$} & B5.3) Negotiates and tops the competition price & \multirow{6}{*}{16,01} & 0,720 & 0,754 & \multirow{6}{*}{0,922} \\
\hline & $\begin{array}{l}\text { B5.5) Offers the best prizes and giveaways of the } \\
\text { market when shopping }\end{array}$ & & 0,777 & 0,744 & \\
\hline & B5.6) Has the lowest interest rate of the market. & & 0,796 & 0,806 & \\
\hline & B5.9) Has the lowest market prices. & & 0,799 & 0,819 & \\
\hline & $\begin{array}{l}\text { B5.11) Has the best promotions and offers of the } \\
\text { market }\end{array}$ & & 0,822 & 0,802 & \\
\hline & $\begin{array}{l}\text { B5.12) Has the best payment c onditions of the } \\
\text { market. }\end{array}$ & & 0,809 & 0,751 & \\
\hline \multirow{4}{*}{$\begin{array}{l}\text { F3 - Social } \\
\text { endorsement and } \\
\text { personal } \\
\text { achievement }\end{array}$} & B5.27) ... a personal achievementl. & \multirow{4}{*}{10,69} & 0,742 & 0,712 & \multirow{4}{*}{0,879} \\
\hline & B5.28) .... status for customers. & & 0,793 & 0,796 & \\
\hline & B5.31) ... achieve others' admiration. & & 0,783 & 0,842 & \\
\hline & B5.32) ... fashionable & & 0,806 & 0,854 & \\
\hline \multirow{4}{*}{$\begin{array}{l}\text { F4 - Store } \\
\text { appearance and } \\
\text { assistance }\end{array}$} & B5.1) Has good assistance. & \multirow{4}{*}{10,30} & 0,819 & 0,765 & \multirow{4}{*}{0,869} \\
\hline & $\begin{array}{l}\text { B5.2) Has salespeople who know well the products } \\
\text { they sell }\end{array}$ & & 0,775 & 0,735 & \\
\hline & & & 0,736 & 0,719 & \\
\hline & $\begin{array}{l}\text { B5.40) Stores in the (question B4.1) are ... Messy } \\
\text { (disorganized) / Organized }\end{array}$ & & 0,625 & 0,660 & \\
\hline \multirow{3}{*}{ F5 - Convenience } & B5.17) Has stores in easily accessible locations for me & \multirow{3}{*}{9,65} & 0,886 & 0,874 & \multirow{3}{*}{0,878} \\
\hline & B5.18) Has products that meet my needs. & & 0,762 & 0,649 & \\
\hline & B5.21) Has stores in location I find convenient. & & 0,856 & 0,838 & \\
\hline \multirow{3}{*}{ F6 - Products } & B5.13) Has a large variety of products & \multirow{3}{*}{8,40} & 0,791 & 0,708 & \multirow{3}{*}{0,880} \\
\hline & B5.15) Has great availability of products in stock. & & 0,792 & 0,708 & \\
\hline & B5.16) Offers products that are good quality brands & & 0,805 & 0,638 & \\
\hline \multirow{2}{*}{$\begin{array}{l}\text { F7 - Tradition and } \\
\text { respect in the } \\
\text { market }\end{array}$} & B5.22) It is respected in the market. & \multirow[b]{2}{*}{5,16} & 0,893 & 0,697 & \multirow[b]{2}{*}{0,901} \\
\hline & B5.23) It has tradition in the market. & & 0,849 & 0,728 & \\
\hline
\end{tabular}

Source: Research data 
Comments: VE - Variance explained of the factor; $\mathrm{h}^{2 \mathrm{~b}}$ - Commonality of the variable; $\mathrm{CF}^{\mathrm{c}}$ - Load factor.

The final factor solution ended up with seven factors, which received the following designations: F1 - Emotional aspects; F2 - instrumental aspects; F3 - Social endorsement and personal achievement, F4 - Store Appearance and assistance; F5 - Convenience; F6 - Products; and F7 - Tradition and respect in the market.

\subsubsection{Average variance extracted and composite reliability}

The measure of composite reliability is an estimate of the reliability coefficient and represents the percentage of the constructs variance that is free from random errors. Table 5 shows the results for the constructs of the model.

Table 5 - Average Variance Extracted (AVE) and composite reliability (CC)

\begin{tabular}{l|ll}
\hline Factors & AVE & CC \\
\hline F1 - Emotional aspects & 0,65 & 0,93 \\
F2 - Instrumental aspects & 0,70 & 0,93 \\
F3 - Social endorsement and personal achievement & 0,78 & 0,93 \\
F4 - Store's appearance and assistance & 0,76 & 0,93 \\
F5 - Convenience & 0,63 & 0,83 \\
F6 - Products & 0,70 & 0,88 \\
F7 - Tradition and respect in the market & 0,73 & 0,84 \\
\hline
\end{tabular}

Source: Research data

According to Tabachnick and Fidel (2001), the AVE should be greater than 0.50 and composite reliability greater than 0.70 , the obtained results show that all constructs were measures of adequacy of the measurement, well above acceptable limits.

\subsubsection{Convergent validity}

The method used in this study to assess the convergent validity was proposed by Bagozzi, Yi and Philips (1991). After running the analysis it was verified that the variables Q31 and Q32 did not show convergent validity. Thus, these variables were excluded from the model.

\subsubsection{Discriminant validity}

To evaluate the discriminant validity of the constructs the method developed by Fornell and Larcker (1981) was applied. The results show that it is possible to attest the discriminant validity for all pairs of constructs based on the method proposed by Fornell and Larcker (1981). 


\section{EXPLICATIVE PHASE}

Structural Equation Modeling was chosen as the adequate multivariate technique to verify the model in this research. The process of direct estimation was chosen, and the covariance matrix was used as the entry matrix, as suggested by HAIR et al. (1998). The estimation method used for this research was ML, which according to HAIR et al. (1998), is an adequate estimation method when the data are moderately not normal. This was, therefore, the procedure adopted. The structural relations for the validation of hypothesis and models were carried out using the software AMOS 4.0 from SPSS. The estimate model is shown in Figure 3.

FIGURE 3 - Complete Structural Model - ML - Standardized Loads. Source: Research data.

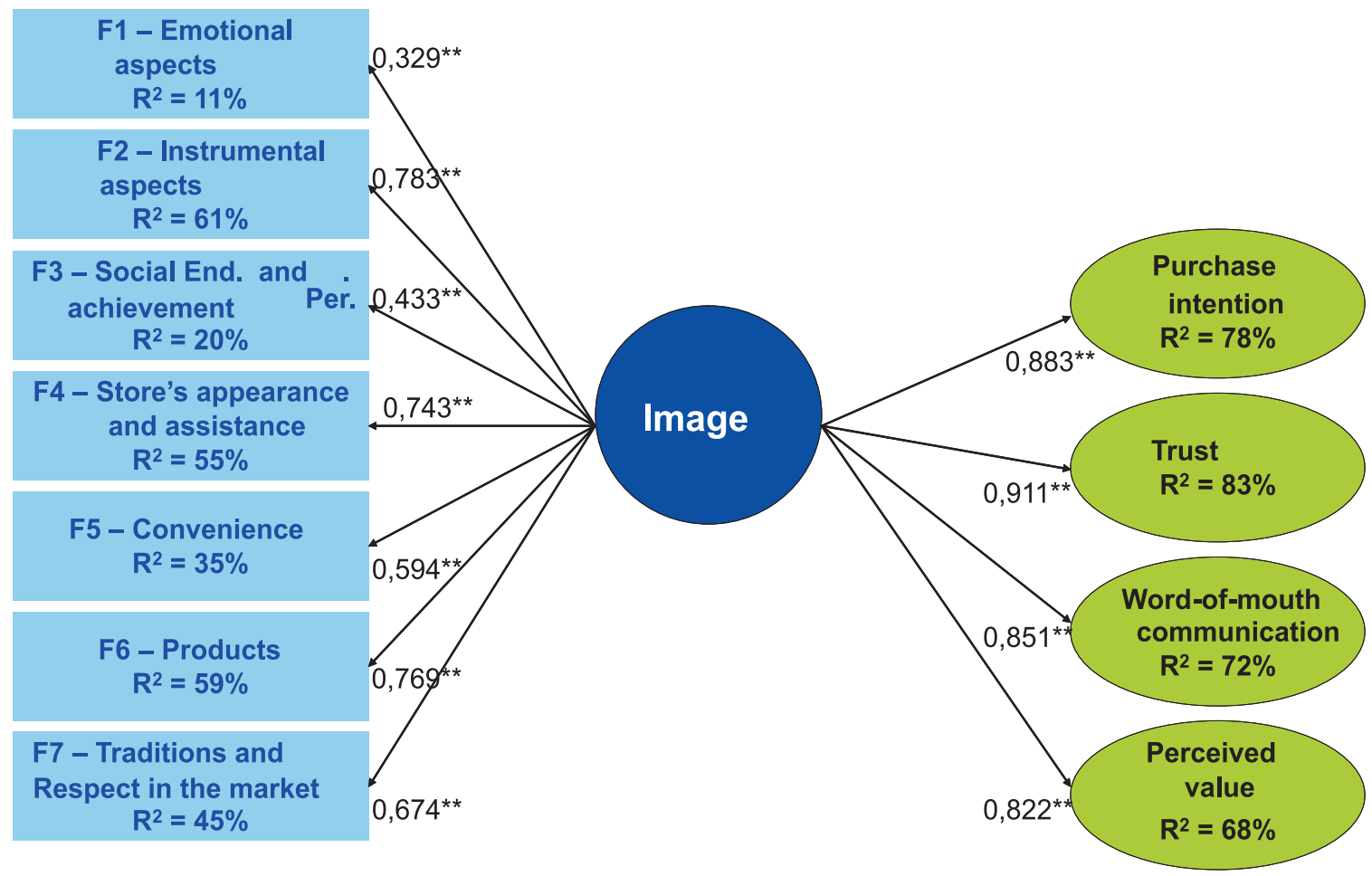

The model adjustment indicators are shown on table 6 .

Table 6 -The model adjustment indicators with all constructs

\begin{tabular}{l|l}
\hline \hline \multirow{2}{*}{ Adjustment measures } & Estimation method \\
\cline { 2 - 2 } & ML \\
\hline Chi-square & 1680 \\
\hline Grade of Freedom & 590 \\
\hline P-value & 0,000 \\
\hline Chi-square-degrees of freedom & 2,84 \\
\hline RMR & 0,271 \\
\hline GFI & 0,866 \\
\hline RMSEA & 0,061 \\
\hline \hline
\end{tabular}


The incremental adjustment indexes (GFI, AGFI, NNFI, CFI) get very close to the cutoff of 0,90 . Another result that contributes to this model acceptance is the qui-square normalized $(\div 2 / \mathrm{gl})$, whose value must be inferior to 3,0 , as mentioned by Latif $(2000$, p. 60$)$. As the result was 2,84 , it is concluded that the model is acceptable.

\section{CONCLUSIONS}

Observing the constant results in Figure 3, it is verified that the "Instrumental" aspects (price and negotiation) have a bigger impact on the retailer's image, demonstrating that the target public is relatively objective in the choice of retailers in this segment. But although these consumers focus on the price in the image's choice and evaluation process, it is highlighted that this is only about their price perception and not necessarily about the price itself, that is, the retailers considered to have a better price hold the best image, even if these prices are not offered.

On the other hand, the second most impacting factor on the image is "Product" (quality/ variety/availability), once again proving that consumers that have the acquisition of the product (and the advantages that come from its use/possession) as their final goal, care significantly about its characteristics and in this respect, need the retailer's endorsement which assures its quality and availability.

The third most impacting factor on the image is "Store appearance and Assistance", calling the attention to how the image and expectations of the relation and interaction with the salesperson, as well as the retailer's experience, affect the purchase decision. In this project's qualitative phase, it was observed that empathy with the salesperson was a key factor in the purchase as well as in the re-purchase, reinforcing the results obtained in the quantitative phase.

Considering the results obtained, attention is drawn to the strong impacts of the Image in the behavioral intentions, especially in Purchase Intention and Word-of-Mouth. Image explained $78 \%$ of Purchase Intentions and $69 \%$ of word-of-mouth. These are high rates, that lead us to believe the scale of the elaborated image has a reasonable nomologic validity, and its managerial use (to predict purchase behavior) can be recommended.

The results of this work lead us to believe that, when choosing electronics retailers, the consumer makes an internal search in his memory tracing back the Image he has of these, created by previous experiences, word-of-mouth and mass communication among other elements. Eminently instrumental in his analysis, the consumer establishes an objective criterion of choice, but uses subjective perceptions from the retailers to decide, which in a way, makes for an interesting contrast.

In what concerns the theory, it is believed that the development of an image scale for the retail would be a relevant contribution, and accordingly, this study can generate a base for future studies and its validation in a broader sense. On the other hand, the image model's test involving behavioral intentions in the retail contributes towards the understanding of the explanation of consumer's behavior in this segment. 


\section{REFERENCES}

AAKER, David A. Managing brand equity: capitalizing on the value of a brand name. New York: The Free Press, 1991. 299p.

AMA. American Marketing Association. Disponível em: < http://www.marketingpower.com. Acesso em: 5 jan. 2006.

.. Definition of marketing. Disponível em: <http://www.marketingpower.com/AboutAMA/ Pages/DefinitionofMarketing.aspx>. Acesso em: 11 jun. 2008.

$$
\text { Disponível em:<http:// }
$$

www.marketingpower.com $>$. Acesso em: 11 jun. 2008.

BACHA, M. L. Semiótica aplicada ao marketing: o potencial comunicativo do signo-marca. In: ENANPAD, 29., 2005, Brasília. Anais... Porto Alegre: Pallotti, 2005. p. 1-616.

BAGOZZI, Richard P.; YI, Youjae; PHILIPS, Lynn W. Assessing construct validity in organizational research. Administrative Science Quartely, v.36, n.3, p.421458, Sept. 1991.

BARICH, H; KOTLER, P. A framework for image management. Sloan Management Review, v. 2, n. 3, p. 94-104, 1991.

CUNHA, F. Avaliação da imagem percebida de três hipermercados junto a consumidores da grande São Paulo. 2001. Tese (Doutorado em Administração)Universidade de São Paulo, São Paulo, 2001.

DE TONI, D. Administração da imagem de produtos: desenvolvendo um instrumento para a configuração da imagem de produto. 2005. 267f. Tese (Doutorado em Administração)-Escola de Administração, Universidade Federal do Rio Grande do Sul, Porto Alegre, 2005.

DE TONI, D.; MILAN, G. S.; SCHULER, M. In: ENCONTRO NACIONAL OS PROGRAMAS DE PÓSGRADUAÇÃO EM ADMINISTRAÇÃO, EnAnPAD, 28., 2004, Curitiba. Anais eletrônicos... Curitiba: ANPAD, 2004.

Configuração de imagens de serviços: um estudo aplicado aos serviços de fisioterapia disponibilizados por um plano de saúde. In: ENANPAD, 29., 2005, Rio de Janeiro. Anais eletrônicos... Rio de Janeiro, 2005.
DICHTER, E. What's in an image. The Journal of Consumer Marketing. v. 2, n. 1, Winter, 1985.

DICIONÁRIO HOUAISS DA LÍNGUA PORTUGUESA. Disponível em: <http://houaiss.uol.com.br>. Acesso em: 24 set. 2007.

DOBNI, D.; ZINKHAN, G.M. In search of brand image: foundation analysis. Advances in Consumer Research, v.17, n.1, p.110-119, 1990.

ENIS, Ben. An analytical approach to the concept of image. Californian Management Review, v. 9, p.5158, 2001.

EYSENC, M.W.; KEANE, M.T. Psicologia cognitiva: um manual introdutório. Porto Alegre: Artes Médicas, 1994.

FORNELL, C.; LARCKER, D. F. Evaluating structural equation models with unobservablevariables and measurement error. Journal of Marketing Research, v. 18, p. 39-50, Feb. 1981.

GRASSELI, M. Marketing na arquitetura: um hiato entre a imagem e a identidade profissional. 2007. 145f. Dissertação (Mestrado em Administração)-Faculdade de Ciências Econômicas Administrativas e Contábeis, Universidade FUMEC, Belo Horizonte, 2007.

GRASSELI, M. F; SOUKI, G. Q. Imagem e posicionamento profissional: um estudo exploratório sobre o marketing na Arquitetura. In: ENCONTRO DA ANPAD - ENANPAD, 31., 2007, São Paulo. Anais eletrônicos... São Paulo, 2007.

HAEDRICH, G. Images and strategic corporate marketing planning. Journal of Public Relations Research, v. 5, n. 2, p. 83-93, 1993.

HAIR, Joseph; ANDERSON, Rolph; TATHAM, Ronald; BLACK, William. Análise multivariada de dados. Tradução de Adonai Schlup Sant'Anna e Anselmo Chaves Neto. São Paulo: Bookmam, 2005.

HAUSEN, Denise Costa. Imagem, lugar de criação. Revista do CEP de PA, Porto Alegre, v. 12, p. 11-122. 2005.

IACOBUCCI, D. Os desafios do marketing. São Paulo: Futura, 2001.

IASBECK, L.C.A. Imagem empresarial: o lugar do cliente. In: CONGRESSO BRASILEIRO DE CIÊNCIAS DA COMUNICAÇÃO, 22., 1999, Rio de Janeiro. Anais... Disponível em: http:// www.intercom.org.br/papers/xxii-ci/gt18/18103.pdf. Acesso em: 10 jan. 2007. 
IBOPE MONITOR. Almanaque Ibope. Disponível em: http://www.almanaqueibope.com.br. Acesso em: 28 jun. 2008.

JUNG, C.G. Estudos sobre o simbolismo do si-mesmo. Petrópolis: Vozes, 1982.

KASULIS, J.; LUSCH, R. Validating the retail store image concept. Journal of the Academy of Marketing Science, v.9, p. 419-435, Fall 1981.

LEVY, S. J. Interpreting consumer mythology: a structural approach to consumer behavior. Journal of Marketing, v. 45, n. 3, p. 49-61, Summer 1981.

LINDQUIST, J. Meaning of image: a survey of empirical and hypothetical evidence. Journal of Retailing, v. 50, n. 4, p. 29-39, 1975.

LOVELOCK, C.; WRIGHT, L. Serviços marketing e gestão. Tradução de Cid Knipel Moreira. São Paulo: Saraiva, 2001. 416p.

MALHOTRA, N. K. Pesquisa de marketing: uma orientação aplicada. 4. ed. Porto Alegre: Bookman, 2006.

MARTINEAU, P. The personality of retail store. Harvard Business Review, v.36, n.1, p.47-55, Jan./ Feb. 1958.

MAY, E.G. Pratical applications of recent retail image research. Journal of Retailing, v.50, n.4, p.15-20, Winter 1974.

MELHORES E MAIORES. Publicação da revista Exame, São Paulo: Abril, 2007.

NETEMEYER, R. G.; BEARDEN, W. O.; SHARMA, S. Scaling procedures: issues and Applications. London: SAGE, 2003.

PLATÃO. A República. 8. ed. Tradução e notas de Maria Helena Rocha Pereira. Lisboa: Fundação Calouste Gulbenkian, 1996. 513p. (livro VII, p.317322)

POIESZ, T. B. C. The image concept: it's place in consumer psychology. Journal of Economic Psychology, North-Holland: Elsevier Science Publishers B.V., n.10, p.457-472, 1989.

RAFFAELI, Rafael. Imagem e Self em Plotino e Jung: Confluências. Revista Estudos de Psicologia, Campinas, v. 19, n. 1, p. 23-36, jan./abr. 2002.

REARDON, J.; MILLER, C.; COE, B. Applied scale development: measurement of store image. Journal of Applied Business Reseach, v. 2, n. 4, p. 85-93, Fall 1995.
REYNOLDS, T. J.; GUTMAN J. Advertising is image management. Journal of Advertising Research, v. 24, p.21-37, 1984.

SALLES, F. A imagem. Disponível em: <http:// www.mnemocine.com.br/filipe $>$. Acesso em: 24 set. 2007.

SANTAELLA, L; NÖTH, W. Imagem: cognição, semiótica, mídia. 3. ed. São Paulo: Iluminuras, 2001.

SCHUBERT, R. Compreendendo as áreas de atuação da psicologia e seus vieses. Disponível em: <http:// w w w. re nes c h u bert.hpg. com.br/ Historia\%20da\%20Psicologia.htm.> Acesso em: 23 set. 2007.

SETH, J N; MITTAL, B; NEWMAN, B I. Comportamento do cliente: indo além do comportamento do consumidor. Tradução de Lenita M R Esteves; Revisão Técnica de Rubens C. Santos. São Paulo: Atlas, 2001.

SOUKI, G. Q.; AMORIM, A. P. de A.; MENDES, R. L. Functional and emotional image in physiotherapy: an exploratory study using drawing techniques. Aberdeen: Academy of Marketing Annual Conference, 2008.

SWAN, J.; FUTRELL, C. Increasing the efficiency of the retailer's image study. Journal of the Academy of Marketing Science, v. 8, p.51-57, Winter 1980.

SWARTZ, T. A. Brand symbols and message differentiation. Journal of Advertising Research, v. 25, n. 23, p. 59-64, Oct./Nov 1983.

STERNBERG, R. J. Psicologia cognitiva. Tradução de Maria Regina Borges Osório. Porto Alegre: Artmed, 2000.

TABACHNICK, B. G.; FIDELL, L. S. Using multivariate statistics. 3. ed. New York: HarperCollins, 2001.

TAVARES, Mauro Calixta. A força da marca: como construir e manter marcas fortes. São Paulo: Harbra, 1998.

WORCESTER, R. M. (1986) Corporate image research. In: WORCESTER, R. M; DOWNHAM, J. Consumer market research handbook. Amsterdan: ESOMAR, 1986. p. 601-616.

ZIMMER, M.; GOLDEN, L. L. Impresions of retail stores: a content analysis of consumer images. Journal of Retailing, v. 64, n. 3, p. 265-293, Fall 1998.

ZEITHAML, V. A.; BERRY, L. L.; PARASURAMAN, A. The behavioral consequences of service quality. Journal of Marketing, v. 60, p. 31-46, Apr.1996. 